\title{
THE DUBLIN
}

\section{QUARTERLY JOURNAL \\ or}

\author{
MEDICAL SCIENCE.
}

FEBRUARY 1, 1858.

\section{PART I. \\ ORIGINAL COMMUNICATIONS.}

Art. I.-On the Rise of the Dublin School of Midwifery; with Memoirs of Sir Fielding Ould, and Dr.J. C. Fleury'. By Alfred H. M'Clintock, M. D., F. R. C.S., M. R. I. A., Master of the Lying-in-Hospital, and President of the Dublin Obstetrical Society.

Gentlemen of the Obstetrical Society,-It is not, I assure you, without great diffidence that I occupy this place tonight. Under any circumstances I would feel the position a most trying one; but on the present occasion it is peculiarly so, as the time seems so short since I had the privilege of addressing you before from this Chair. I am, however, sensibly alive to the honour your Council have done me in requesting that I would open this Session of the Society with an introductory address.

This request I should, without hesitation, have declined, did it not so happen that I had by me some materials towards the history of three men whose names are intimately-I might say indissolubly-connected with the establishment and the

a The Introductory Address to the Dublin Obstetrical Society, at the Opening of its Twentieth Session.

VOL. XXV. NO. 49, N. s. 
fame of our National School of Midwifery. Such a topic I knew could not fail to meet with a favourable reception from the members of the Obstetric Society: nay more, I feel it would be considered by you as a fit and worthy subject to be incorporated into an inaugural discourse.

Under this conviction I accepted the invitation. I was anxious that due respect should be shown to the memories of those eminent individuals; at the same time, I was well aware that the amplest indulgence would have to be conceded towards the manner in which the subject would be brought before you. But, Gentlemen, having so often experienced the indulgence of this Society, I could not doubt of its liberal extension on an occasion like the present.

We meet this evening under circumstances of peculiar interest. Our Society has commenced its twentieth session; and proud I am to see around me on this occasion so many of its tried friends and able supporters. It is true, indeed, that few of those who assisted at its inauguration in the year 1838 are now amongst us. That "few" includes some who were then just entering as candidates in the eager race for public confidence and professional distinction, but who now occupy the enviable and honored position of the heads of our department. Others, who at that period were active labourers in the obstetric field, have since retired from it, matured in reputation, and having reaped the golden harvest of their industry and their talent. In this favoured class, who have thus attained to that summum bonum which constitutes the culminating point of our worldly expectations and ambition, I am happy to find the name of Dr. Evory Kennedy, the founder of this Society.

Lastly, others there were whose names and whose works alone remain to us ; they themselves have passed "beyond that bourne whence no traveller returns." I rejoice, however, to think that their places are occupied by cultivators of obstetric science not less ardent than they were, and who possess the additional advantage of their example to stimulate and encourage them.

But, Gentlemen, we commemorate another and far more important event on the present occasion. This great Hospital, within whose precincts we are assembled, and of which our Society is but the later offspring, will shortly enter upon the second century of its existence. The benefits which have resulted from its establishment may be said, without hyperbole or exaggeration, to be incalculable.

As it was the first, so we find it has been the model of every institution of the kind in the wide extent of the British Em- 
pire. It has gained for this city pre-eminent celebrity as an obstetric school; and it has thereby contributed its full share towards sustaining the character of the Irish School of Medicine generally.

Although it is strictly true that this Hospital was opened for patients on the 8th of December, 1757, still it is deserving of remembrance that its founder, Bartholomew Mosse, had, twelve years previously, established, at his own expense, in South George's-street, a lying-in hospital, which he maintained in active operation until the present building was fit for the reception of patients.

As a charity for the relief of human suffering in its most trying form, as a seminary for practical instruction in midwifery, and as a source of obstetric data, this Hospital has more than realized the most sanguine expectations of its founder. In support of these assertions, I may mention, first, that over 183,000 women have been admitted into the Hospital during the century just closing; secondly, that since the year 1786, upwards of 5000 pupils, from every part of the civilized world, have received their obstetric education within its walls ${ }^{\mathbf{a}}$; and lastly, that it has given to the world the well-digested statistical results of above 47,000 cases of labourb. Such a collection of minute obstetric data, relating to every variety and complication and phase of parturition and its consequences, has not been published by any other hospital.

To dilate upon this subject would be a gratifying, but superfluous task.

Of those whom I now have the honour to address, few, if any, are not the alumni of this Hospital. Of its value they have had personal experience; and in its history, intimately associated as it is with that of the Obstetric School of this city, they must feel more than a passing interest.

I have, therefore, thought that it would not be inappropriate to the present time and occasion to lay before you, Gentlemen, some notices of persons and incidents connected with this Hospital in the earlier part of its existence.

a For the first thirty years no official registry was kept of the pupils attending the Hospital.
b Viz. :-DD. Joseph Clarke's Report, . . . . 10387 cases.
Dr. Collins' Report, . . . . . . 16414
Drs. Hardy and M'Clintock's Report, 6634
Drs. Jobnston and Sinclair's Report, 13768
$"$
,
Total, .... 47203

Drs. Johnston and Sinclair's Report will very shortly be published, as it is now nearly out of the printer's hands. 
The history of its founder, Bartholomew Mosse,--his exertions, his devotion, and his extraordinary perseverance,- has been ably sketched by Mr. Wilde in the second volume of the Dublin Quarterly Journal of Medical Science. Ample justice is there done to the exalted character and far-seeing wisdom of this great philanthropist. One circumstance relative to Mosse's early medical history I may be permitted to mention, as it has escaped notice in the paper just alluded to. He is occasionally styled Surgeon and Man-mid wife, or Surgeon and Licentiate in Midwifery. His surgical diploma, Mr. Wilde tells us, was granted (as was customary then) by the Surgeon-General; but the other (license in midwifery) was a degree conferred by the King and Queen's College of Physicians, and qualified or licensed the holder to practise midwifery. On searching the Minutes of the College, I find under the date of May 3, 1742, the following record:- "Agreed that Mr. Mosse and Mr. Carter have a license granted them for practising midwifery, having been examined and approved." The Mr. Carter here named is, I presume, the same individual who, in conjunction with Fielding Ould, fulfilled the medical duties of the Hospital during the nine months' interval between the death of Mosse and the appointment of his successor in the office of Master.

It is here worthy of mention, that at a very early period the importance of midwifery was fully recognised in this city. Before the year 1715 (how long I cannot exactly say), the King and Queen's College of Physicians had instituted a special examination in obstetrics, and to those gentlemen whose answering was approved of, a license was granted. In 1743 a Professorship of Surgery and Midwifery was founded. The Royal College of Surgeons, within the first year of its incorporation (1784), established a Professorship of Midwifery, and also a distinct examination in the same, and the successful candidates received a diploma authorizing them to practise this branch of the healing art.

The ceremony observed on the opening of the Hospital is thus quaintly described by a contemporary historian. The Duke of Bedford, then Lord Lieutenant, her Grace the Duchess, and a great number of the nobility and gentry, were entertained at breakfast at the Hospital, after which "fifty-two poor women, great with child, who attended in the hall with proper certificates for admission, and were all decently clothed in uniform at the expense of the Hospital, each in a blue calimanco gown and petticoat, shift, handkerchief, cap, and apron; and thus they appeared before his Grace as President of the Hospital, the Duchess, and the rest of the Governors and Guardians, with 
many of the nobility and gentry, who all expressed the highest satisfaction. During the whole time of breakfast, and the ceremony of opening the Hospital, their Graces and the company were entertained with a concert of vocal and instrumental music, and everything was conducted in the most regular, easy, and genteel manner."

Mosse did not long survive the achievement of what had been the great object of his life. He had, indeed, the supreme gratification of seeing the Hospital finished, and patients regularly received into its wards; and in contemplation of the asylum which his genius and perseverance had provided, he might with all truth have exclaimed-

\section{"Exegi monumentum ære perennius."}

The intense and constant strain upon his mental energies, together with severe bodily fatigue, had by this time greatly impaired his bodily health. In the beginning of the winter of 1758 (within twelve months from the opening of the Hospital), he was confined to his chamber; later in the year he was removed for change of air to Cullenswood; and on the 16th February, 1759, in the forty-seventh year of his age, he breathed his last.

"Thus," to quote the words of his biographer, Mr. Wilde, " died this great and good man, in the prime of life and usefulness, possessing great energy and high benevolence of character, which he so employed as to have conferred immeasurable benefit upon his own and subsequent generations. His eulogy is to be found in his acts. Without fortune, without influence, without patronage, without precedent, he conceived the project of affording relief to a certain class of the community; and with extraordinary energy, prudence, and perseverance, never relaxing, never despairing, he carried it into execution at an expense of character, station, and pecuniary independence."

May we not truly apply to him the beautiful language of Grattan, and say, "that in feeding the lamp of charity, he had exhausted the lamp of life"?

Immediately after his death Mr. (afterwards Sir Fielding) Ould, and Dr. Carter, volunteered to superintend the management of the Hospital until a Master was elected. Both these gentlemen wiere appointed by the Board to take charge of the patients month about. At the Charter Board, in the following November (1759), Mr. Ould was elected Master of the Hospital in the room of Mosse, and he proved himself in every way a worthy successor of this great man. His earnest zeal in 
the welfare of the institution is amply attested by the fact, that for twenty-eight years he took an active and leading part in the management of its affairs, and was a constant attendant at the boards and committees. His name is familiar to us all, and is held in just respect amongst us, even by the many who know but little of his writings, and nothing of his life or character.

The literary reputation of the Dublin School of Midwifery commenced with Fielding Ould, and his treatise, original and excellent in itself, was but the earnest and forerunner of a numerous succession of works on the same and kindred subjects that in after years emanated from this city ${ }^{\mathrm{a}}$.

Sir Fielding Ould was descended from an ancient English family. His grandfather, Colonel Ould, came to this country in the army of King William III., and commanded the Royal Regiment of Welsh Fusileers (subsequently the 23rd Regiment Royal Welch Fusileers) at the Battle of the Boyne.

After the surrender of Dublin, the superior officers of the conquering army were admitted freemen of the city, and the names of Colonel Ould, and of his son, Captain Ould, are to be found on the Freemen's roll.

The colonel and his son were present at the battle of Aughrim, after which engagement the Welsh Fusileers were quartered in Galway. Captain Ould there married a Miss Shawe, the daughter of a gentleman of that county, and had by her two sons,-Fielding, the subject of the present sketch, born about 1710, - and another named Abraham. Captain Ould was a few years afterwards assassinated at night in the streets of London, whereupon his widow returned to her father in Galway, who, being a gentleman of ample fortune, brought up his grandsons at his own expense. Fielding became a surgeon and accoucheur, and Abraham a barristerb.

It is more than probable that Fielding Ould received his medical education in some of the continental schools; and, indeed, we learn from the preface to his book, that at all events

\footnotetext{
a The principal of these separate and independent works are-Jebb on the Process of Labour ; Dease's Observations in Midwifery ; Foster's Lectures upon Midwifery; Brenan on the Use of Turpentine in Puerperal Fever; Douglas on Spontaneous EvoIution; M'Keever on Rupture of the Uterus; Maunsel's Dublin Practice of Midwifery; Travers Burke's Accoucheur's Vade Mecum; Kennedy on Obstetric Auscultation; Montgomery's Exposition of the Signs and Symptoms of Pregnancy; Maunsel and Evanson on the Diseases of Children; Collins' Midwifery; Churchill's Theory and Practice of Midwifery ; Churchill's Operative Midwifery; Churchill on Diseases of Women; Churchill on the Diseases of Children; Hardy and M'Clintock's Practical Midwifery ; Sinclair and Johnston's Practical Midwifery.

b For this history of the Ould family I am indebted to John Morrison, Esq., M. D., whose mother was a grandchild of Sir Fielding.
} 
he studied midwifery in Paris, and very possibly under the celebrated Gregoire, who about that period enjoyed great reputation as an obstetric teacher.

It was during this sojourn in Paris, whilst yet a young and comparatively inexperienced accoucheur, that he made the ob. servation of the lateral position of the head-a discovery of great practical importance, and perfectly original with him. This shows that he was a man who observed and reasoned for himself, and possessed in a high degree accuracy of observation. and independence of mind.

He settled down to practise here somewhere about 1736 or 1737 , and seems from the first to have devoted himself principally, if not exclusively, to midwifery. He obtained the license in midwifery of the King and Queen's College of Physicians, August 16,1738. An entry to this effect appears on the Minutes of the College for that day, and is as follows:"Memorandum, that Mr. Fielding Ould was examined for a license to practice midwifery, and, being found singularly well qualified, was licensed accordingly." It may be remarked here that the date of his obtaining the obstetric license of the College of Physicians is nearly four years prior to the time of Mosse's getting the same: from which, and other circumstances, I am led to infer that Ould was in point of age the senior of the two by about a couple of years.

His " Treatise of Midwifery" was published in 1742, though written, and perhaps printed, the year before. It is dedicated to the President, Censors, and Fellows of the College of Physicians in Dublin, and has facing the title-page a testimonial of approval, signed by Francis Le Hunt, Brian Robinson, Henry Cope, Robert Robinson, and Edward Barry, in their official capacities: the first as President, and the rest Censors, of the College; - the work having been referred to them (November 2,1741 ) for an opinion of its merits, by the College at large, to whom Ould had submitted it for approval.

This Treatise was, I believe, the first work upon midwifery published in this country: nay more, if we except the writings of Chapman and Sir Richard Manningham, it was in fact the first obstetric treatise having any pretensions to merit and originality which appeared in the English language. But, independently of this, the work possessed intrinsic merits of a superior kind, and contained many new observations of great importance; so much so that we would leave it to any impartial and competent reader to say whether it is not superior to any English obstetric treatise published before that of Smellie in 1752 . 
Although at the risk of appearing tedious to some present who are familiar with Ould's writings, I still cannot forbear noticing a few of the points, his observations upon which show the superiority and the accuracy of his obstetric knowledge: evidencing, at the same time, how much he was in advance of his contemporaries in these and other matters relating to midwifery.

1. In contradiction to Mauriceau and numberless other writers upon the gravid uterus, Ould maintained that the thickness of its parietes did not diminish, but rather increased, as pregnancy advanced-a fact which is now clearly established, and known to every tyro.

2. Our author successfully combats the views of Deventer, who laboured to prove that the greatest difficulties in delivery proceed from obliquity of the uterus; whereby, as Ould quaintly remarks, "he has made an otherwise small treatise upon midwifery swell into a large volume." Deventer's work appeared in the eighteenth century. It was written in the Latin language, but was subsequently translated into French. The doctrine which it promulgated had been received with great applause by many persons of note in the profession. But Ould was not a man to be blindly led by authorities. His discernment and observation showed him the absurdity of this theory. In a few short sentences he destroys the entire foundation of Deventer's doctrine, and demolishes the imposing superstructure raised upon it.

3. The instrument invented by Ould for lessening the head-viz., the terebra occulta, though completely and justly superseded by the perforator, was still, I think, a better and much safer instrument than any of those in use when he began to practise. The principal objection to the terebra occulta is, that with it we cannot enlarge the opening into the cranium: an objection which does not apply to the scissors of Smellie, or to the perforator of later years.

4. In referring to the use of the forceps, he lays it down as a fundamental axiom that it should not be used in the delivery of dead children. This precept may not altogether accord with the teaching of some modern obstetric authorities, or with the alleged results of statistical computation; nevertheless, I am very sure it has the full, entire sanction of every unprejudiced and experienced practitioner.

5. Within the last few years we have heard a good deal about turning the footus in cases of slight deformity of the pelvis; and rival claims were advanced for the merit of originating this proposal, In point of fact, however, the merit-be it 
great or small_of originality in this matter, fairly belongs to Ould. I shall quote his own words respecting the practice in question:-

"Suppose a woman in labour, who, by the experience of a former delivery, was found by the operator to have the passage through the bones of the pelvis so narrow as to refuse an exit to the child (though not of an extraordinary size) by means of the common efforts of nature, and that on this account it died, or was destroyed by instruments for the preservation of the mother's life. In this case there is a strong probability of saving the child by introducing the hand when the membranes break, and bringing it forth by the feet. . . . . . It may be objected that the same narrowness of the passage through the pelvis, which hindered the natural expulsion with the head foremost, may hinder its extraction when brought forth by the feet; this is also allowed; but yet, if we consider the matter properly, it will appear that by drawing from a small end, which is the feet, in order to bring forth the larger, with the additional assistance of holding the legs in one hand, and having the finger of the other in the child's mouth, there is a far greater probability of bringing it forth than when the large end comes first."

6. The most original observation in this Treatise of Ould's, and that upon which his title to fame most securely rests, is the statement respecting the position of the head during its transit through the pelvis-namely, that the face is directed to one side or other of the pelvis, and not towards the sacrum, as was the universally received doctrine. Dr. Rigby, in his translation of Naegèle, pronounces this observation to be the "punctum saliens" of all our knowledge respecting the mechanism of parturition. In the present assembly, the importance of a right understanding of this mechanical process need not be enlarged upon. It lies at the foundation of all our obstetric practice, and gives midwifery more pretensions to being a science than is possessed by physic or surgery. It is true the full exposition of this subject was reserved for other observers-namely, Solayres de Renhac, Baudelocque, and Naegèlé; but we must never forget that the first step in this demonstration was made by Fielding Ould.

7. In this brief enumeration of the prominent merits of Ould's Treatise, it would be unjust not to mention his strongly expressed opinion of the necessity for a consultation in all cases of difficulty, and especially where a resort to craniotomy seems imperative. At the present day the importance of this duty is fully recognised, but it was very different a hundred 
years ago. The accoucheur could then scarcely ask for a consultation without exposing himself to the imputation of ignorance. It showed, therefore, in Ould no small degree of sound judgment and moral courage, thus to oppose the general sentiment. He advocates this line of conduct on the same grounds, and for the same reasons, as are now admitted without hesitation by all practitioners, as well as by the public.

It could scarcely be expected that a work which contained so much that was new, and which unsparingly assailed many established obstetric doctrines, would fail to provoke censure and controversy. What the critics of the day said of it I am unable to discover; but we can well suppose that Ould's book created no small sensation, when a work of nearly equal size was written and published for the express purpose of " showing his Errors in Anatomy, the Danger and Bad Consequences attending his Practice and Manner of Delivery." The author of this critical treatise was a Dr. Thomas Southwell, who dates the preface "from his house in Kildare," and styles himself "M.D. \& Man-midwife". Although this author displays considerable critical acumen, and literary acquaintance with his subject, still it is easy to see that he was destitute of candour or originality. Every new observation put forward by Ould he rejects as unfounded; nor will he even admit that there is the least merit in any part of his Treatise.

Thus the position that Dr. Southwell took in relation to Ould was precisely similar to that of Dr. Burton, in later years, to Smellie. The only difference between those annotators is, that Burton as an author is only known from the fact of his having written against Smellie (for he is also known to the readers of Tristram Shandy, under the name of Dr. Slop), whilst Southwell and his Treatise are both alike forgotten.

It is not a little curious that Burton, in his "Letter to Smellie," cites Ould as an authority upon one of the points at issue between them.

Dr. Southwell, in a rather scornful way, describes Ould as being " the youngest surgeon practising in midwifery in the city," which seems probable enough.

I have mentioned that Ould became Master of the Hospital in November, 1759. At that time this officer was not a Governor de virtute offciii; but Ould was elected a Governor the May following (1760), and the same month the honour of knighthood was conferred upon him by John Russell, fourth Duke of Bed-

- This work consists of two parts, the first of which appeared in 1742, and the second in 1744. Both are to be found in the Library of the College of Surgeons, among the "Medical Tracts," vols. xeii. and xvii. 
ford, who was then Lord Lieutenant, and President of the Board of Governors and Guardians of the Hospital. What the "causa honoris" was, is uncertain; but Gilborne, in his poem of the "Medical Review," thus describes it:-

"Sir Fielding Ould the sword of knighthood gained

For saving ladies' lives in child-bed pained."

When a cockney wit of the present day suggested that a living accoucheur of eminence, if raised to the peerage, should be styled "Lord Deliver-us," he was probably unaware that a Dublin wit had, nearly a century ago, deprived him of the merit of originality by the following epigram on the occasion of Ould's being knighted:-
"Sir Fielding Ould is made a knight, He should have been a lord by right; For then each lady's prayer would be, o Lord, good Lord, deliver me!"

His professional career was one of unusual length, extending from about the year 1736 or 1738 to 1788 , - that is, over half a century, during which period he had among his patients many of our highest nobility. From certain facts with which $I$ have been made acquainted by some of Ould's immediate descendants, I entertain no doubt whatsoever that he it was who attended the Countess of Mornington at the births of the Marquis of Wellesley, and of the still more illustrious Arthur, Duke of Wellington.

This distinguished honour has been claimed for Dr. M'Bride; but his biographer in the "Dublin Quarterly"a has clearly proved that there exists no grounds for such a suppositionnay, more, the Countess of Mornington does not appear' to have been at any time a patient of Dr. M'Bride's.

Sir Fielding was the innocent cause of a very serious rupture between the University and the College of Physicians, whereby a connexion which had subsisted between these two bodies for more than sixty years was dissolved. How this came about was as follows:-In October, 1759, Mr. Ould presented to the College of Physicians a liceat from the University to be examined for a Bachelor's degree in physic.

This the College flatly refused to do, it being contrary to their by-laws and to their ideas of professional dignity that any of their body should practise midwifery. The University, notwithstanding, conferred an honorary degree in medicine 
upon Sir Fielding, which act seems to have roused the indignation of the College to the highest degree. They construed it into a deliberate expression of contempt for their by-laws, an encroachment on their privileges, and an insult to their body at large. At a meeting of the College held February 5th, 1761 , it was agreed that the University, in conferring a degree in physic on Sir Fielding Ould, had treated the College with very great and undeserved disrespect; and it was further resolved that the connexion subsisting between the College and the University, by virtue of the agreement dated July 25 th, 1701 , should be dissolved.

Not satisfied with these resolutions, they ordered a letter to be written to the Provost, the gist and purport of which are contained in the concluding sentence:-

"We do declare that for the future we will not examine your candidates, nor officiate at the performance of their public acts; and that we will receive into our College the graduates of other universities, if sufficiently recommended by their learning and morals, though not admitted ad eundem in yours."

Thus, you see, ended a compact which was framed in a rather illiberal spirit of monopoly, unworthy the dignity and abridging the usefulness of the two bodies. Both of them have, I think, good reason to feel obliged to the man whoindirectly and unwittingly, it may be-brought about its abrogation.

Sir Fielding Ould's residence was No. 21, Frederick-street, South. North Frederick-street, I may mention, was not then built,- the ground whereupon it now lies being an open space called "The Barley Fields." His house was pulled down some years ago, and its site is now partially occupied by the house No. 12, Nassau-street, which forms the east corner of this street and Frederick-street.

His death took place the 29 th November, $1789^{\mathrm{a}}$, at his residence in Frederick-street; and he was interred in the burying-ground adjoining St. Anne's church. The date of his interment appears in the Parish Registry, but $I$ have not been able to find any memorial tombstone or monument of him.

His professional income must have been very considerable for many years of his life; and there is no doubt he realized a respectable fortune from this source. He was married to a Miss Walker, of this city, by whom he had several children.

One of his descendants was good enough to place at my service the portrait in crayons from which the lithograph

Walker's Hibernian Magazine, vol. xix. p. 672. 
likeness accompanying this paper was taken. The fac-simile of his signature is from an autograph in my own possession.

In drawing a parallel between these two distinguished men, - Mosse and Ould,-we find that their histories present several points of resemblance and of contrast.

They lived at the same period; they practised the same branch of the profession; they were licensed by the same College; they both contributed (though each in a different manner) to found an obstetric reputation for this city; and the memories of both are to the present hour held in deep respect amongst us.

Such are the points in common between them: now observe those of contrast.

Mosse, on the one hand, is famous for having established a great practical school. To effect this, he zealously devoted all his time, his energies, and his fortune. He just lived to see this object achieved, and no more; he died in the prime of manhood. The grateful admiration of posterity, and "the blessing of those who are ready to perish," constitute his reward.

Ould, on the other hand, by his Treatise upon Midwifery, laid the foundation of the fame of this city in obstetric literature. His well-earned reputation gained for him an extensive and lucrative practice, and he acquired wealth by the honest exercise of an honourable calling, and died in the fulness of years.

Both these men are justly eminent, but their merits and their rewards are very different.

Sir F. Ould's Mastership terminated in the beginning of November, 1766. To him succeeded Mr. Henry Collum, who had been Assistant to Ould, and was the first person who filled this office. Mr. Collum was one of the Surgeons to Steevens' Hospital, and is thus alluded to in Gilborne's Medical Review:-

"Who Collum calls is certain of a cure,-

A skilful surgeon and wise accoucheur;

Long did he govern kind Lucina's shrine;

Oft re-elected, in that station shine;

Where he presided with superior powers,

Till crouded Business filled his vacant hours."

During his Mastership, and so early as the year 1770, the propriety of courses of lectures upon midwifery being delivered to the pupils of the Hospital began to engage the serious attention of the Governors: their object being, as would appear, not merely to render the system of instruction here more com- 
plete, but to obtain for the diploma or certificate of the Hospital the force and authority of a regular license or degree in midwifery, such as was then the practice of the College of Physicians to issue.

For reasons which cannot now be clearly made out, the discussion of this question gave rise to a warm controversy, in the progress of which recourse was, as usual, had to the press, and several pamphlets were published, some approving and others denouncing this measure of instituting lectures here. Of these pamphlets, one, which took the affirmative side of the question, was entitled, "A View of the schemes at present under the consideration of the Governors of the Lying-in Hospital." No name was attached; but the author in the course of his remarks named an eminent contemporary physician, and called upon him, as a public man and known teacher of midwifery, to state openly his opinion upon the question at issue.

The physician so appealed to was Dr. John Charles Fleury. As the name of this accoucheur thus unavoidably comes under notice, I trust to be excused for making here a short digression to give a brief sketch of his life. $\mathrm{He}$ is deserving of this, as his name is honourably associated with the history of midwifery in this city.

Dr. Fleury was born in 1733, took his degree in Edinburgh in 1760 , and settled in Dublin as a practitioner of medicine and midwifery. He was Physician to the Meath Hospital for twenty-three years, viz., from 1763 to 1786 , when he resigned. For the last fourteen years he was Senior Physician to the Hospital. He gave several regular courses of lectures upon midwifery and the diseases of women and children; and to render these lectures practical, he was in the habit of attending with his class poor women in labour at their own homes. He commenced lecturing about the year 1761 or 1762 , and discontinued in 1769. 'These lectures, curious to say, were delivered in the Anatomical Theatre of Trinity College, and with the sanction, though not by the authority, of the Board. The way this came about was as follows:-Fleury applied to the Board through Dr. Mercier, one of the Senior Fellows (and afterwards rector of Omagh), for permission to use the Anatomical Theatre as a lecture-room : which request the Board refused to grant " unless Dr. Fleury produced a testimonium or certificate, signed by the Medical Lecturers upon the College foundation" (who then were Drs. Hutchinson, Cleghorn, and Span), "that his proposed lectures were likely to be of use, and that they thought him qualified to give them ;" which certificate they readily furnished. 
All the researches I have been able to make upon this subject justify me in claiming for Dr. Fleury the merit of having been the first regular lecturer upon midwifery and the diseases of woman and children in this city. It is true, there was at this time, and from the year 1743, a Professor of Surgery and Midwifery attached to the College of Physicians; but there is good reason to believe that midwifery formed a very insignificant part of his course ; and in 1785 it was superseded by anatomy. The only rival claim that $I$ am aware of, is that of Dr. Edward Foster, whose posthumous work on Midwifery was edited by Dr. James Sims of London, and published in 1781ª . But Foster was not elected an Assistant of the Hospital till July, 1772 ; and it is barely possible that he lectured on midwifery previously to this. Gilborne thus speaks of Foster in the Medical Review, published in 1775 :-
"Judicious Foster feels the latent pulse,
To hidden maladies gives quick repulse;
In parturition brings propitious aid,
Each dame retrieves that has by him been laid.
He teaches pupils, either sex apart,
In learned lectures, his mysterious art."

The first lecturer upon midwifery in Edinburgh is supposed to have been Dr. Young, who gave private courses in or about 1751, and was elected Professor of Midwifery in 1756. He had two predecessors in this Chair, but neither of them lectured . In 1770 Dr. Denman, in conjunction with Dr. Osborne, began to read lectures on midwifery, in London, having purchased the apparatus, \&c., of Dr. Cooper, " man-midwife" to the Middlesex Hospital. The credit of having been the first public lecturer of midwifery in Britain is given by Denman to Dr. John Maubray, the author of "The Female Physitian," and of "Midwifery brought to perfection by manual operation." He endeavoured to make himself famous by decrying the forceps, and extolling the hand as a preferable means of assisting women in difficult labours. He gave lectures at his house in Bond-street, about the year 1724 .

Dr. Fleury having been appealed to in the way I have al-

a'The Principles and Practice of Midwifery. By Edward Foster, M.D., late Teacher of Midwifery in the City of Dublin : completed and corrected by James Sims, M. D. London: 1781 ; 8vo, pp. 316 . This is a good treatise upon midwifery, and remarkable for the terse, aphoristic style in which it is written.

b For these and other interesting matters relating to the "Rise of the Edinburgh School of Midwifery," see Dr. Malcolm's paper in the Edinburgh Medical Journal, July, 1856 . 
ready mentioned, felt constrained to publish his sentiments upon the question, which he freely considered in all its bearings. His pamphlet is not less remarkable for elegance and clearness of style, than for the sound views which it contains, and the good sense which it discloses in every observation. He utterly rejects the idea that mere attendance at a lying-in hospital, and upon obstetric lectures, could make a man fit to practise midwifery. "The most enlightened professor of midwifery,", he writes, " never can hope by the best digested course of lectures upon that subject to make a skilful accoucheur of one who has not a competent knowledge of anatomy, chemistry, in short, of all the præcognita of physic"a.

Dr. Fleury was for many years an active member of the Medico-Philosophical Society ${ }^{b}$, and communicated to it several papers of interest. One of these, upon " The Epidemic Cold of 1775," was thought worthy of being published a few years ago in the fifth volume of the Dublin Quarterly Medical Journal, and is well worthy of perusal. Of his other papers, two were on obstetrical subjects; and may therefore, be alluded to here. At a meeting of the Society, December 7, 1775, he read the history of a case of ruptured uterus, with complete recession of the child; and he lays it down as a maxim that "complete recession of the head after it has been for some time presenting, is a pathognomonic sign of a ruptured uterus." There is no doubt that of individual signs this is one of the most reliable; and it is much to the author's credit that this observation was made ten years before Andrew Douglas' celebrated monograph on "Rupture of the Uterus" was published.

In December, 1777, Dr. Fleury detailed to the Society, with great clearness, a case of retroversion of the uterus, occurring about the third month of pregnancy. It seems he recognised the true nature of the case, but it being the first of the kind he had ever seen, he called in the aid of his friend, Dr. Jebb, then Master of this Hospital, who replaced the womb; but in the course of some time after it fell down again, on which second occasion Dr. Fleury returned it himself, and the lady went to the full time. This case is interesting as having been, in all probability, the first of the kind here, in which the diagnosis was

a Probably the only copy extant of this able and well written pamphlet is one bound up in the thirty-ninth volume of "Pamphlets," in the Library of the Royal Dublin Society.

This Society was established in 1756 : many of the leading physicians belonged to it, and read papers at its meetings. Three large manuscript volumes of its Transactions are preserved in the Library of the College of Physicians. For a further account of the Society, see vol, i. of this Journal, p. xxviii., New Series. 
established. Ten years previously, the first recorded case in England took place, and came under the notice of Dr. William Hunter; and during the decade which followed, only five cases seem to have been met with in all England.

I have in my possession a volume of MS. lectures, eightyfive in number, on Materia Medica, by Fleury; but whether these were ever delivered or not, I cannot positively say; I have good reason, however, to think they were. These lectures seem to have been prepared with much care, and by their sound practical teaching prove the author to have been a man of enlarged experience and accurate observation.

In November, 1784, Dr. Fleury was elected a Licentiate of the King and Queen's Colle'ge of Physicians, "without examination or expense." If not the first, he certainly was one of the first practitioners of midwifery upon whom such an honour was conferred by this body.

Dr. Fleury lived in Stephen's-street, No. 51, and towards the latter end of his life in South Great George's-street, nearly opposite Exchequer-street. On his tombstone in the 'graveyard at Dundrum, county of Dublin, we read the following epitaph:- " Here lieth the body of John Charles Fleury, an eminent and ingenious Physician, whose cheerfulness and social wit rendered him the delight of his friends. He died suddenly, on the 29 th of September, 1797, aged 64, universally regretted."

During the latter years of his life Dr. Fleury was nearly quite blind, and had retired from practice. He, was an accomplished classical scholar, having been educated at a time when an intimate acquaintance with the dead languages, especially Latin, was indispensable to the physician. For many years of his life he never eat meat, and held the practice almost in disgust; he remained fixed in his vegetarian principles to the last. Dr. Fleury was never married.

Dr. Gilborne, in his "Medical Review," or "Panegyric on the Faculty of Dublin: physicians, surgeons, and apothecaries marching in procession to the Temple of Fame," thus speaks of this physician:-

"Fleury can symptoms of diseases tell, Symptoms of symptoms can distinguish well; Assist the labours of the groaning wife, And saves the infant's and the mother's life."

Let me now return from this digression.

Although the Hospital Board determined in November, VOL. XXV. No. 49 , N. S. 
1770 , as we have seen, that the room off the grand hall (at present known as No. 9 ward) should be fitted up, and apparatus provided for lectures on midwifery and the diseases of women and children; and also that Dr. M.Bride would be a proper person for Lecturer,-yet the execution of these resolutions was delayed till the latter end of the year 1774, in the May of which year Dr. M'Bride was elected a Governor of the institution. At the request of Dr. Frederick Jebb, who was now the Master, and with the approval of the Board, Dr. M·Bride commenced lecturing here about the latter end of this year or the beginning of 1775 .

Dr. Jebb succeeded Mr. Collum as Master in November, 1773; and was the first who resided in the Hospital. He was generally supposed to be the author of an anonymous work dedicated to Dr. M‘Bride, and entitled, "A Physiological Inquiry into the Process of Labour, and an attempt to ascertain the determining cause of it" (Dublin, 1770). This book has become very rare; one copy of it is contained in the Library of the College of Surgeons ${ }^{\mathrm{a}}$. The author candidly states in the dedication that "the principles of the work are the property of the ingenious M. Petit, King's Professor of the Royal Garden at Paris." Thus to renounce all claim to originality for his work is creditable to the author's candour: I must confess it raises him still more in my estimation to think that he did not originate the theory which the book contains, as it is about as great a tissue of gratuitous absurdity as ever was fabricated under the semblance of scientific truth! Indeed, I can say little for this Treatise. The only good thing in it is the entire rejection of the notion that parturition is effected, in any degree whatsoever, by the movements or efforts of the foetus.

Jebb appears among the Doctors whom Gilborne poetically describes as " marching in procession to the temple of Fame;" and is thus introduced:-

“'There's Fred'rick Jebb who the Hospital commands

Where pregnancy's relieved by skilful hands;

An edifice magnificent and large,

Kept up with splendour at the public charge.

In France perfectioned in Lucina's ways,

For happy births he's crowned with verdant bays."

In the winter of $1774-5 \mathrm{Dr}$. M'Bride began to lecture here and I have the authority of Dr. Collins for stating that he delivered several courses of lectures for the benefit of the pupils

"It is bound up in volume lxxv. of "Medical Tracts." 
attending the Hospital ${ }^{a}$. It is more than probable, therefore, that he continued lecturing up to the time of his last illness in 1779. Dr. Jebb's term of office expired the year following; and Surgeon Henry Rock was elected Master. $\mathrm{He}_{\mathrm{e}}$ died in office, as did Mosse, in 1759 - and Dr. Pentland in 1826.

Rock was, I believe, a surgeon to Steevens' Hospital, but seems to have been chiefly noted for his obstetric skill, as Dr. Gilborne thus speaks of him among the surgeons of this (Steevens') Hospital:-
"The matrons who rely on Henry Rock
With safety can increase their tender stock:
In time of danger his relief is good,
He saves the mother and the infant brood.
Fame in his praise employs her silver tongue;
Nor will the Muses leave his acts unsung."

To Dr. Rock succeeded, in the year 1786, Dr. Joseph Clarke, whose name must ever hold a prominent place in the annals of this hospital, and among the obstetric celebrities of this city. To give any sketch of his life or writings would be wholly needless, as Dr. Collins' published Memoir of him must be known to all of you.

Dr. Clarke opened a new era in the history of the Hospital, and distinguished his government of it-firstly, by being the first Master to deliver courses of lectures to the pupils; secondly, by establishing an official registry of the names of pupils attending the practice of the Hospital; and thirdly, by introducing a plan of ventilating the wards, that has been productive of the most signally beneficial results.

Since then it has been the custom for each Master to give two or more courses of lectures in each year, in the discharge of which duty the Assistants generally take a part.

I must now bring this rather desultory address to a close. Of its many defects no one, perhaps, is better aware than I am myself. But when we go to gather up the fragments of the past, we must be content to take them as they come, without seeking to shape or connect them according to our wishes or ideas.

To contribute in any degree towards perpetuating the fame of those eminent men spoken of in this paper is to me a source

"Dr. M'Bride's biographer, in vol. iii. of this Journal, has not noticed the circumstance of his having lectured here upon midwifery. It is worthy of note, however, as showing his varied attainments, and the estimation in which he was held.

c 2 
of much satisfaction. I trust, moreover, that in recalling their memories and achievements, I have not merely afforded you gratification, but have supplied to all of us fresh stimulus to co-operate in maintaining the character of that obstetric school of which they were the founders and most distinguished ornaments.

Ant. II.-A Remarkable Case of Carotid Aneurism, with extraordinary Complicationsa. By S. Henry Hobart, A.B., M.B.T.C.D., M. R. C. S. E., Medical Officer, Cork Dispensary.

George Sinick, a baker, aged 40, was admitted into the North Infirmary, under my father's care, August 28, 1857, with aneurism of the carotid artery. On the left side of the neck there is seen an immense tumour, which, from its great size, and the absence of all redness on the surface, gives at first sight somewhat the idea of strumous abscess; on closer inspection, however, it is seen to pulsate very distinctly: this is quite obvious to the eye, and sufficiently denotes the nature of the tumour; still, the surgeon examining it is quite unprepared for the intense thrill that is felt over the entire surface on laying his hand on the part. On applying the stethoscope, and placing the ear within an inch or two of the other end, a remarkably loud bruit is heard, and when the ear is brought in contact with the stethoscope, the sound becomes quite painfully loud; it is, moreover, very distressing to the patient himself, who says that he feels as if he had a steam-engine at work in his head, which altogether prevents his getting a sound or refreshing sleep.

The tumour extends from half an inch to the right of the mesial line at the chin along the inferior maxilla, to a point about an inch behind the left ear, where its boundary is indefinitely lost; from this it passes downwards to a very short distance from the clavicle; it completely fills the digastric space (appearing to extend upwards under the maxillary bone); it also occupies the entire of the anterior superior triangle of the left side, as also the greater part of the inferior, and even extending considerably into the posterior triangles; superiorly it is on a level with the jaw, or is rather more elevated; posteriorly it is insensibly lost over the trapezius muscle; anteriorly also, at its upper part, it is badly defined, but its lower border

a Read before the Cork Medical and Surgical Society. 